(c) American Dairy Science Association, 2004.

\title{
Short Communication: Impact of Formulation on Ice Cream Microstructures: an Oscillation Thermo-Rheometry Study
}

\author{
C. Granger,${ }^{1,2}$ V. Langendorff, ${ }^{2}$ N. Renouf, ${ }^{2}$ P. Barey,${ }^{2}$ and M. Cansell ${ }^{1}$ \\ ${ }^{1}$ Laboratoire "Milieux dispersés alimentaires: physico-chimie, \\ formulation et vectorisation nutritionnelle", \\ ISTAB, Université Bordeaux 1, France \\ ${ }^{2}$ Degussa Food Ingredients, \\ Business Line Texturant Systems France SAS, France
}

\section{ABSTRACT}

Oscillation thermo-rheometry was used to underline the existence of the different microstructures in ice cream. Varying ice cream formulations illustrated the impact of each ingredient, i.e., fat, proteins, and lipid emulsifiers, and their interactions on the establishment of different networks.

(Key words: ice cream, rheology, lipid emulsifier - proteins - fat formulation)

Ice creams are described as polyphasic food systems including ice crystals, air bubbles, isolated and partially coalesced fat globules, and a cryo-concentrated aqueous phase containing sugars, proteins, and polysaccharides (Goff, 2002). All these components form a complex colloidal system that includes different microstructures. While several studies showed that rheometry correlates well with ice crystals (size and connectivity) and the air fraction volume (Goff et al., 1995; Wildmoser et al., 2003), this technique has not yet been used to characterize the fat globule and protein networks. The present work aims to correlate the rheological properties of ice creams and their different microstructures using various incomplete formulations.

Ice cream formulations contained $8 \%$ refined coconut oil (SIO, France), $10 \%$ skim milk powder (Coopérative d'Isigny Saint-Mère, France), 12\% sucrose (Saint Louis, France), 6\% corn syrup solids (Cerestar, France), 0.2\% stabilizer (guar gum and locust bean gum, Degussa Food Ingredients, France) and 0.3\% partially unsaturated mono-di-glycerides (Degussa Food Ingredients). Model ice creams were prepared without proteins or lipid emulsifiers that were replaced by sucrose. Homogenized mixes were prepared and aged at $4^{\circ} \mathrm{C}$ as described by Granger et al. (2003). Ice creams (overrun

Received October 8, 2003.

Accepted December 16, 2003.

Corresponding author: M. Cansell; e-mail: m.cansell@istab. u-bordeaux1.fr. orders: $100 \%$, outlet temperature $-5^{\circ} \mathrm{C}$ ) were made in a continuous freezer (Waukesha Cherry Burrell WCB CS 100) then, hardened at $-40^{\circ} \mathrm{C}$ and stored at $-25^{\circ} \mathrm{C}$. Ice cream processing was carried out in duplicate. Mean particle size diameter (evaluated by the volume weighted average diameter $\mathrm{d}_{4,3}$ ) and particle size distribution of oil droplets in mixes and final products were determined by integrated light scattering using a Mastersizer 2000 (Malvern Instruments SA). Samples were diluted in the sample chamber with water or dissociative medium, $1 \%$ SDS, at approximately 1:1000. The percentage of partial coalescence of fat was calculated on the basis of particles with diameters higher than 2 $\mu \mathrm{m}$ as the difference between the proportions measured in the presence of SDS in the initial mix and final product. Measurements on ice creams were performed using ultrasonication to ensure the absence of air bubbles. The rheological measurements were performed using a controlled stress rheometer (Physica MCR 300) fitted with streaked parallel plates (1 $\mathrm{mm}$ gap). Before being placed on to the rheometer, the products were thermostatically controlled for $2 \mathrm{~h}$ at $-10^{\circ} \mathrm{C}$. The samples were left for $15 \mathrm{~min}$ in the rheometer before the experiment. The storage modulus $\left(\mathrm{G}^{\prime}\right)$, loss modulus $\left(\mathrm{G}^{\prime \prime}\right)$, and damping factor $\left(\tan \delta=\mathrm{G}^{\prime \prime} / \mathrm{G}^{\prime}\right)$ were measured at 2 different deformation amplitudes, i.e., $0.05 \%$ between -10 and $5^{\circ} \mathrm{C}\left(0.2^{\circ} \mathrm{C} / \mathrm{min}\right)$ and $0.1 \%$ between 5 and $60^{\circ} \mathrm{C}\left(0.2^{\circ} \mathrm{C} /\right.$ $\min$ ), at a frequency $\omega$ of $1 \mathrm{~Hz}$. These amplitudes were chosen on the basis of the determination of the linear visco-elastic regime of ice cream by a deformation amplitude sweep test.

For the complete ice cream formulation, fat globule mean diameter evolved from $1.2 \mu \mathrm{m}$ in the mix to 4.2 $\mu \mathrm{m}$ in the final product. Fat partial coalescence was found close to $3 \%$. The withdrawal of milk proteins from the ice cream formulation led to an increase in the fat droplets in the mix $\left(\mathrm{d}_{4,3}=2.5 \pm 0.4 \mu \mathrm{m}\right)$, some fat destabilization during freezing (with $18 \%$ of particles partially coalesced) and a lower overrun (40\% instead of $100 \%$ for the other formulations). In contrast, when the lipid emulsifier was removed from the complete 

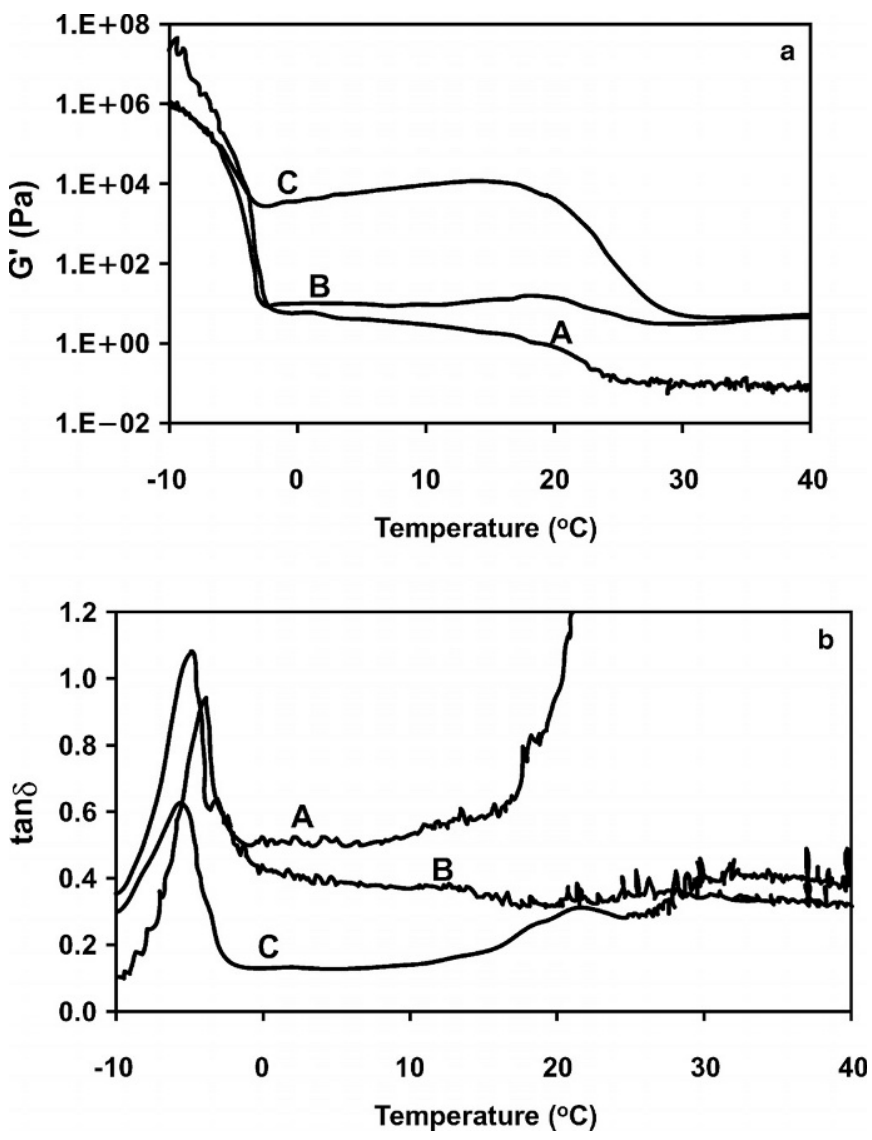

Figure 1. Rheological characteristics, storage modulus $\left(G^{\prime}\right)(a)$ and $\tan \delta(\mathrm{b})$, of different ice cream formulations as a function of the temperature. Incomplete ice cream formulations without proteins (curve A); without lipid emulsifier (curve B); and complete ice cream formulation (curve $\mathrm{C}$ ). The curves are typical of at least 2 different preparations.

formulation, a strong steric stabilization of the fat globules was observed throughout the steps of the whole process $\left(\mathrm{d}_{4,3}=1.3 \pm 0.1 \mu \mathrm{m}\right.$ for the mix and the final product).

The rheological behavior of the complete and the 2 incomplete formulations as a function of temperature showed a steep decrease in the storage modulus between -10 and $-2^{\circ} \mathrm{C}$ (Figure 1a) associated with a peak in the damping factor (Figure 1b). In this temperature range, $\mathrm{G}^{\prime}$ variations were correlated with a loss of cooperative interactions between ice crystals associated with their melting (Goff et al., 1995; Wildmoser et al., 2003) and $-2^{\circ} \mathrm{C}$ corresponded to the ice melting temperature of our system calculated according to Bradley and Smith (1983). Because the 3 samples behaved similarly in the negative temperature range, although the products exhibited differences in overrun, fat droplet mean diameters and degree of partial coalescence, it seemed that, in our experimental conditions, thermo-rheometry was not able to detect structural differences at these temperatures, most probably because the systems were overwhelmed by the presence of ice. Between $-2^{\circ} \mathrm{C}$ and $17^{\circ} \mathrm{C}, \mathrm{G}^{\prime}$ values and $\tan \delta$ stabilized, at different values depending on the formulation (Figure 1a and b). In the case of the formulation containing only mono-diglycerides as emulsifier, lower overrun and poorly stabilized fat globules led to a weaker and less structured product (curve A, Figure 1a). The replacement of the low molecular weight emulsifier by milk proteins in the incomplete formulation only slightly modified $\mathrm{G}^{\prime}$ values and $\tan \delta$ (curve B, Figure 1a and b), although fat globules were well stabilized against partial coalescence and a $100 \%$ overrun was obtained. When the rheological behavior of the complete (curve C, Figure 1a and b) and incomplete ice cream formulations (curves A and B, Figure $1 \mathrm{a}$ and $\mathrm{b}$ ) were compared between -2 and $17^{\circ} \mathrm{C}$, the magnitude of the storage modulus $\mathrm{G}^{\prime}$ clearly characterized a stiff and well structured product, suggesting that cooperative interactions between the different ingredients had taken place. This behavior could be related to the presence of a partially coalesced fat network. However, the influence of the melting of the locust bean gum cryo-gel, enhanced by phase separation from the proteins and/or the smaller air bubble size could not be excluded. Between 17 and $30^{\circ} \mathrm{C}$, for all formulations, a decrease in the storage modulus was observed in relation to complete fat melting. However, a peak of $\tan \delta$ was only present for the ice cream product. This corresponded to the disappearance of the fat globule network. In the case of the formulation containing only mono-di-glycerides as emulsifier, the loss modulus decreased more slowly than the storage modulus $(\tan \delta$ higher than 1 at $20^{\circ} \mathrm{C}$ ), resulting in a system that responded less elastically with increasing temperature (curve A, Figure 1b). In contrast, similar and lower $(<1)$ $\tan \delta$ values obtained from the incomplete formulation, based on proteins only (curve B, Figure 1b) and the ice cream product (curve C, Figure 1b), indicated the existence of a remaining microstructure. This could be attributed, at least partly, to the presence of proteins in association with stabilizers. Moreover, the fact that these 2 formulations reached similar $\mathrm{G}^{\prime}$ values above $30^{\circ} \mathrm{C}$ (curves B and C, Figure 1a) suggested that interactions between milk proteins and fat took place to ensure a structured product.

This study demonstrated that the rheological characteristics of ice creams were related to the existence of different microstructures (ice, dispersed air, partially aggregated fat phase and aqueous phase) that influenced the final texture either simultaneously or individually as a function of the temperature range considered. 


\section{ACKNOWLEDGMENTS}

The authors acknowledge the Degussa Food Ingredients group and the National Association of Technical Research for their financial support through a Ph.D. research grant for C. G. The authors would also like to thank Alan Critchley for rereading this article.

\section{REFERENCES}

Bradley, R., and K. Smith. 1983. Finding the freezing point of frozen desserts. Dairy Rec. 84:114-115.
Goff, H. D., B. Freslon, M. E. Sahagian, T. D. Hauber, A. P. Stone, and D. W. Stanley. 1995. Structural development in ice creamDynamic rheological measurements. J. Texture Stud. 26:517536.

Goff, H. D. 2002. Formation and stabilisation of structure in icecream and related products. Curr. Opin. Colloid Interface Sci. $7: 432-437$.

Granger, C., P. Barey, N. Combe, P. Veschambre, and M. Cansell. 2003. Influence of the fat characteristics on the physicochemical behavior of oil-in-water emulsions based on milk proteins-glycerol esters mixtures. Colloids Surf. B: Biointerfaces 32:353-363.

Wildmoser, H., J. Scheiwiller, and E. J. Windhab. 2003. Impact of disperse microstructure on rheology and quality aspects of ice cream. Pages 291-295 in Proc. 3rd Int. Symp. on Food Rheology and Structure, Zurich, Germany. 